\title{
History and Current Situation of Education for Children with Disabilities in Cambodia: A Gray Literature Review
}

\author{
Akihiro Nishio \\ Health Administration Center, Gifu University, Gifu, Japan \\ Email: a_nishio@gifu-u.ac.jp
}

How to cite this paper: Nishio, A. (2019). History and Current Situation of Education for Children with Disabilities in Cambodia: A Gray Literature Review. Creative Education, 10, 1753-1763.

https://doi.org/10.4236/ce.2019.108125

Received: March 29, 2019

Accepted: August 3, 2019

Published: August 6, 2019

Copyright $\odot 2019$ by author(s) and Scientific Research Publishing Inc. This work is licensed under the Creative Commons Attribution International License (CC BY 4.0).

http://creativecommons.org/licenses/by/4.0/ Open Access

\begin{abstract}
In this paper we report on historical changes in the Cambodian education system, the current state of education for persons with disabilities. This report is based on interviews with Mr. Pen Thavy, materials provided by the Cambodian government, and other supporting documents. The first turning point in Cambodia's movement toward educating children with disabilities was the "Convention on the Rights of the Child" adopted by the United Nations General Assembly on November 20, 1989. Cambodia ratified this treaty in 1992. The concept of "Education for All" was adopted into educational policy in Cambodia. The first law directly mentioning education for children with disabilities was the "Educational law" enacted in 2007. The Schools specialized in education for children with disabilities are operated by three NGO schools. One is the Krousar Thmey Foundation which operates 8 schools for children with visual/hearing impairment. Another one is Rabbit-School which accepted 26 students in the special class, 25 students in the readiness class for children aged 4-to-6 years, 18 students in classes for children with cerebral palsy and 46 students in the integrated class. The third one is Komar Pilar Foundation which does not have coordination with the government and is not officially regarded as a school. According to the data which we were given, the total number of students with all disabilities was 44,759 in primary schools and 6787 in secondary schools in 2017. Most common disability was emotional disturbance in primary schools and visual impairment in junior high schools. The data show that the number of invisible disabilities such as behavioral disorders, learning disability, intellectual disability and emotional disturbance varied so much in each province. Misidentification of disabilities can be considered a cause for it.
\end{abstract}

\section{Keywords}

Special Education, Inclusive Education, Disability, Special Support Education, 


\section{Research Background}

In Cambodia, the private sector has been responsible for educating all children with disabilities. However, in 2020 the education of children with visual and hearing impairments will be moved to the public education sector. Until then, special education schools and support for students with visual and hearing impairments are provided by the Krousar Thmey Foundation. On September 15, 2017, we interviewed Mr. Pen Thavy, Director of Special Education at the Ministry of Education, Youth and Sports in Cambodia. In this paper we report on historical changes in the Cambodian education system, the current state of education for persons with disabilities, and Cambodia's future plans regarding the education of children with disabilities. This report is based on interviews with Mr. Pen Thavy, materials provided by the Cambodian government, and other supporting documents.

Cambodia is located in the southern part of the Indochina Peninsula, facing the Gulf of Thailand in the south, Thailand in the west, Laos in the north, and Vietnam in the east. Cambodia's land area is $180,000 \mathrm{~km}^{2}$ and inhabited by approximately 15 million people. Ethnically, $86 \%$ of the country's population is Khmer, $5 \%$ is Vietnamese, $5 \%$ is Chinese, with the remaining $4 \%$ comprised of other ethnic minorities. Cambodia's constitution establishes Theravada Buddhism as the national religion, though religious freedom is guaranteed. More than 90\% of the population believes in Buddhism. According to the International Monetary Fund, Cambodia's gross domestic product per capita in 2014 was 1094 dollars (Cambodia GDP, 2019), which is less than 10\% of the world's average. According to the data released by the Asian Development Bank in 2011, it is estimated that $68.2 \%$ of Cambodian citizens live on less than two dollars a day. (ADB Economics Working Paper Series, 2011). Based on United Nations standards, Cambodia is ranked as a least developed country.

\section{Education System in Cambodia}

\subsection{Before the Civil War}

In this paper we position 1979 as post-civil war period, when Pol Pot factions withdrew from Phnom Penh and Heng Samrin established his regime. This is because the movement toward the modern Cambodian system is consistently cited as following the Heng Samrin government. The educational history of Cambodia before the end of the civil war is detailed in Mr. Chankea Phin's "The Historical Transition of the Educational System in Cambodia-Social Characteristics in the Education System before the Paris Peace Agreement" (Chankea, 2013). Here we present a timeline of educational changes based on this paper.

In the pre-modern era, like in most Southeast Asian countries, education in 
Cambodia was mainly provided in Hindu and Buddhist temples, and restricted to royalty or the aristocracy. The modern education system was introduced in Cambodia in 1867 at the conclusion of the Convention on Protection between France and Cambodia (Ayres, 2000). In 1893, the College du Protectorate was established as a Cambodian bureaucracy training agency to advance colonial policy, followed by Lycee Sisowath School. In 1906, the French colonial government formed the education improvement committee to promote the modernization of the Cambodian education system (Ayres, 2000). In rural areas, schools installed at the site of the temples ("temple schools") and those set up in villages were regarded as public schools. Teacher training was conducted for monks who had been teaching. In urban areas, public schools were established in each state capital and boys aged 8 and above were eligible to attend. In addition, a higher education institute was established to train administrators.

On November 10, 1911, under the protection policy of France, King Sisowath Monivong issued the first decree on compulsory education. For the first time in Cambodia's history, compulsory education was institutionalized (Masson \& Fergusson, 1997). In the same year, a public school for girls opened in Phnom Penh. However, in general girls' education was neglected, even in the king's ordinance girls' compulsory education was not mentioned.

In 1912, a cabinet order strengthened the compulsory education system by issuing fines to governing agencies neglecting the educational mandate (Bilodeau, Pathammavong, \& Hông, 1955). Furthermore, a 1916 cabinet ordinance allowed males to attend temple schools for compulsory education from first to third grade, but fourth to sixth graders had to attend Franco-Khmer elementary schools. In Franco-Khmer elementary schools, French culture, morality, geography, and history were taught; there were very few lessons on Cambodia. It is thought that the educational system of the French colonial government had little influence on the lives of people living in rural Cambodia. Although formal institutions were maintained, children in rural areas generally went to traditional temple schools. However, temple schools did not sufficiently fulfill the functions of basic education.

In 1953, Cambodia became independent from France and conducted educational reform under the ideology of Buddhist socialism. In reality, there was little substantive change. Also, it was difficult to carry out educational activities during the civil war era that began in 1970 and continued until the collapse of the Pol Pot administration.

\subsection{After the Civil War}

In 1979, Heng Samlin reformed public education and adopted the 4-3-3 system: 4 years of elementary school, 3 years of junior high school, and 3 years of high school (David, 2000). However, the Pol Pot regime continued guerrilla activities and international financial support ceased, as the new Cambodian government was regarded by Western countries as a puppet of Vietnam. Therefore, the number of elementary schools decreased from 5209 in 1979 to 3005 in 1983. 
Since many teachers were lost during the civil war, short term training to surviving teachers and intellectuals was conducted and they were approved as teachers, but only for reading and writing.

By 1981, teacher training schools and the higher normal school (now Royal Phnom Penh University) resumed in Phnom Penh and 20 provincial teacher training schools were established in rural areas. In 1986, a five-year elementary school education system was introduced. This was free and compulsory elementary education was followed by three years of junior high and three years of high school. This system was modified to become the present 6-3-3 system, in effect since 1996 (Hatani, 2011).

Since 2000, the teacher training system in Cambodia has changed dramatically. To become an elementary school teacher, high school graduates must complete a two-year training course at a Provincial Teacher Training College (PTTC). As of 2018, 18 PTTCs have been established throughout the country. To become a junior high school teacher, high school graduates must complete a two-year training course at a Regional Teacher Training College (RTTC). There are also 18 RTTCs nationwide. In order to become a high school teacher, four-year university graduates must complete an additional one-year training course at the National Institute of Education (NIE). NIE is located only in Phnom Penh. There is no restriction on the university major.

\section{Special Education for Children with Disabilities}

\subsection{Education System for Children with Disabilities}

The first turning point in Cambodia's movement toward educating children with disabilities was the "Convention on the Rights of the Child" adopted by the United Nations General Assembly on November 20, 1989 (Convention on the Rights of Children, 1989). Article 28, paragraph 1 states the right to receive education as follows:

States Parties recognize the right of the child to education, and with a view to achieving this right progressively and on the basis of equal opportunity, they shall, in particular 1) Make primary education compulsory and available free to all, 2) Encourage the development of different forms of secondary education, including general and vocational education, make them available and accessible to every child, and take appropriate measures such as the introduction of free education and offering financial assistance in case of need, 3) Make higher education accessible to all on the basis of capacity by every appropriate means, 4) Make educational and vocational information and guidance available and accessible to all children, 5) Take measures to encourage regular attendance at schools and the reduction of drop-out rates.

In other words, the United Nations declared that nations were obliged to provide education according to their abilities to all children, regardless of disability. Cambodia ratified this treaty in 1992.

The concept of "education for all" dominated the "Education Conference for All" in Thailand in 1990, the "Special Needs Education World Conference" and 
its resulting" Salamanca Statement" in 1994. This education for all concepts was adopted into educational policies of Cambodia as well. After the Paris Peace Treaty with the Pol Potist group in 1992, United Nations became the interim governing regime for Cambodia. Under this system, the "Cambodian Kingdom Constitution" (The Constitution of the Kingdom of Cambodia, 2010) was enacted in 1993. In the constitution, the "Protection of children's rights, educational opportunities, welfare" (Article 48) and "Guarantee of public education opportunities" (Article 68) were noted. However, education for children with disabilities was not. The first law directly mentioning education for children with disabilities was the "Educational law" (Education Law, Kingdom of Cambodia, 2007) enacted in 2007. Disabilities were recognized in Articles 38 ("special support") and Article 39 ("rights of learners with disabilities"). Specifically, these rights were: "special education for persons with disabilities in special schools", "the right to learn with not disabled children", "the right to receive additional guidance within the regular education program", and "the right to receive special education in special classes in local schools".

To underscore the 2007 signing of the "Convention on the Rights of Persons with Disabilities" (Convention on the Rights of Persons with Disabilities and Optional Protocol, 2006) the "Cambodian Law on the Protection and the Promotion of the Rights of Persons with Disabilities" (Cambodian Law on the Protection and the Promotion of the Rights of Persons with Disabilities, 2009) was enacted in 2009. This legislation guaranteed school enrollment for children with disabilities (Article 27), the implementation of educational policy for children with disabilities, promotion of inclusive education (Article 28), enrichment of educational facilities for children with disabilities (Article 29), educational consideration for special needs (Article 30), training programs for teachers (Article 31 ), and promoting the understanding of disabilities (Article 32).

In addition, the Disability Action Council (DAC) was established in 1997. DAC is an important semi-governmental association whose role is to connect community groups and government officials and organizations to further support persons with disabilities. The DAC was originally founded to promote and protect the rights of persons with disabilities. In 1999, DAC collaborated with the Ministry of Education, Youth and Sports to start "The project to develop educational opportunities to meet the specific needs of children with disabilities in Cambodia". This project focused on the development of suitable educational opportunities to meet the needs of individuals with disabilities (UNICEF East Asia \& Pacific Regional Office, 2003). Project results were summarized as "Education Policy for Children in Cambodia". This report became a draft for the Ministerial Ordinance "Education Policy for Children with Disabilities in Cambodia" (Education Policy for Children with Disabilities in Cambodia, 2008) issued by the Ministry of Education, Youth and Sports in 2008.

\subsection{Current Situation of Special Education in Cambodia}

The Special Education Division is in charge of education for children with dis- 
abilities. Originally, it handled only education in elementary school. However, as of December 2016, its scope of responsibility expanded to include early childhood and junior high school education. Currently, it is operated by four offices including the department in charge of planning. In Cambodia, disabilities are classified into nine categories: visual impairment, hearing impairment, speech impediment, movement disorder, behavioral disorder, learning disability, intellectual disability, emotional disturbance, and others. The number of Cambodian children in each of these disability categories in elementary and junior high schools in 2017 are shown in Table 1 and Table 2, respectively. These data were individually provided by Ministry of Education, Youth and Sports in Cambodia. The total number of students with all disabilities was 44,759 in primary schools and 6787 in secondary schools. The most common disability was emotional disturbance in primary schools and visual impairment in secondary schools.

The identification of each disability is carried out by teachers in schools, using the check list prepared by the Special Education Division. For example, in the area of intellectual disability, there are seven items used to identify intellectual disabilities. If four of these items are observed, the child is classified as intellectually disabled. The seven items are:

1) Can he/she express his/herself well with words, as compared to other children of the same age?

2) Does he/she seem unable to do what other children of the same age can do?

3) Does he/she have a trouble with emotions and self-reflection?

4) Does he/she speak differently as compared to other children of the same age?

5) Does he/she move differently as compared to other children of the same age?

6) Does he/she play differently as compared to children of the same age (Example: $\mathrm{He} / \mathrm{She}$ does not understand rules of a game).

7) He/She cannot repeat these five words in order: house, book, cattle, tree, family.

The schools that specialize in educating children with disabilities are operated by three nongovernment organizations (NGOs). The Krousar Thmey Foundation is an NGO founded in 1991 with the aim of educating children from refugee camps. In 1994 it opened a school for children with visual impairments and in 1997 a school for children with hearing impairments. The Krousar Thmey Foundation receives some subsidies from the government. Currently, this NGO operates schools for students with visual and hearing impairments in four cities: Phnom Penh, Kampong Cham, Battambang, and Siem Reap. The eight schools currently operated by the Krousar Thmey Foundation will be shifted to the public sector in 2020. Table 3 and Table 4 show the number of students attending each school. Although there are few students with the targeted disabilities, integrated education is also conducted in collaboration with local public schools. Training programs for teachers and intern were provided in these mainstream public schools. Training for elementary school teachers has been completed. 
Table 1. Number of children by disability at each elementary school in Cambodia.

\begin{tabular}{|c|c|c|c|c|c|c|c|c|c|c|c|c|c|c|c|c|c|c|c|c|c|c|}
\hline \multicolumn{23}{|c|}{ Primary School } \\
\hline & & \multicolumn{2}{|c|}{$\begin{array}{c}\text { Visual } \\
\text { impairmenti }\end{array}$} & \multicolumn{2}{|c|}{$\begin{array}{l}\text { Hearing } \\
\text { mpairmenti }\end{array}$} & \multicolumn{2}{|c|}{$\begin{array}{c}\text { Speech } \\
\text { impediment }\end{array}$} & \multicolumn{2}{|c|}{$\begin{array}{l}\text { Movement } \\
t \quad \text { disorder }\end{array}$} & \multicolumn{2}{|c|}{$\begin{array}{c}\text { Behavioral } \\
\text { disorder }\end{array}$} & \multicolumn{2}{|c|}{$\begin{array}{l}\text { Learning } \\
\text { disability }\end{array}$} & \multicolumn{2}{|c|}{$\begin{array}{l}\text { Intellectual } \\
\text { disability }\end{array}$} & \multicolumn{2}{|c|}{$\begin{array}{l}\text { Emotional } \\
\text { disturbance }\end{array}$} & \multicolumn{2}{|c|}{ Others } & \multicolumn{3}{|c|}{ Total } \\
\hline No. & Province & $\stackrel{\frac{0}{\pi}}{\Sigma}$ & 丞 & $\stackrel{0}{\tilde{\Sigma}}$ & 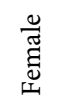 & $\stackrel{\frac{\pi}{\pi}}{\sum^{\pi}}$ & 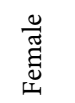 & $\sum^{\frac{\pi}{\Sigma}}$ & 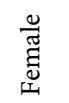 & $\stackrel{\frac{m}{\pi}}{\Sigma}$ & चีّ & $\stackrel{\varrho}{\Sigma}$ & 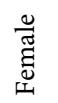 & $\frac{\pi}{\Sigma}$ & 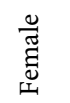 & $\frac{0}{\sum^{\pi}}$ & 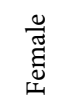 & $\frac{\ddot{\pi}}{\sum^{\pi}}$ & 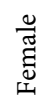 & $\frac{\ddot{\pi}}{\sum^{\pi}}$ & 氶 & 营 \\
\hline 1 & Phnom Penh & 574 & 150 & 125 & 67 & 148 & 108 & 40 & 19 & 34 & 14 & 0 & 0 & 5 & 6 & 780 & 396 & 0 & 0 & 1706 & 760 & 2466 \\
\hline 2 & Kandal & 331 & 150 & 199 & 130 & 166 & 294 & 105 & 53 & 35 & 15 & 0 & 0 & 17 & 11 & 979 & 618 & 0 & 0 & 1832 & 1271 & 3103 \\
\hline 3 & Takeo & 294 & 210 & 265 & 162 & 170 & 342 & 106 & 73 & 33 & 20 & 0 & 0 & 30 & 13 & 1461 & 186 & 0 & 0 & 2359 & 1006 & 3365 \\
\hline 4 & Kampot & 211 & 78 & 103 & 48 & 74 & 138 & 57 & 34 & 10 & 8 & 0 & 0 & 23 & 12 & 637 & 366 & 0 & 0 & 1115 & 684 & 1799 \\
\hline 5 & Kep & 25 & 36 & 12 & 9 & 0 & 36 & 9 & 2 & 3 & 1 & 0 & 0 & 1 & 0 & 127 & 234 & 0 & 0 & 177 & 318 & 495 \\
\hline 6 & $\begin{array}{c}\text { Preash } \\
\text { Sihanouk }\end{array}$ & 34 & 12 & 12 & 4 & 17 & 48 & 7 & 1 & 0 & 0 & 0 & 0 & 0 & 0 & 67 & 24 & 0 & 0 & 137 & 89 & 226 \\
\hline 7 & Koh Kong & 58 & 12 & 23 & 24 & 7 & 24 & 10 & 7 & 2 & 0 & 0 & 0 & 3 & 0 & 58 & 42 & 0 & 0 & 161 & 109 & 270 \\
\hline 8 & Pailin & 16 & 48 & 28 & 20 & 12 & 48 & 11 & 5 & 1 & 4 & 0 & 0 & 1 & 2 & 118 & 114 & 0 & 0 & 187 & 241 & 428 \\
\hline 9 & $\begin{array}{l}\text { Banteay } \\
\text { Meanchey }\end{array}$ & 206 & 222 & 190 & 149 & 169 & 246 & 68 & 44 & 33 & 24 & 0 & 0 & 17 & 7 & 1263 & 888 & 0 & 0 & 1946 & 1580 & 3526 \\
\hline 10 & Battambang & 335 & 234 & 258 & 199 & 162 & 396 & 117 & 66 & 59 & 34 & 0 & 0 & 31 & 28 & 866 & 852 & 0 & 0 & 1828 & 1809 & 3637 \\
\hline 11 & Pursat & 212 & 138 & 179 & 146 & 44 & 414 & 140 & 80 & 114 & 89 & 0 & 0 & 16 & 14 & 773 & 678 & 0 & 0 & 1478 & 1559 & 3037 \\
\hline 12 & $\begin{array}{l}\text { Kompong } \\
\text { Chhnang }\end{array}$ & 106 & 102 & 59 & 48 & 54 & 138 & 48 & 34 & 18 & 11 & 0 & 0 & 13 & 14 & 147 & 210 & 0 & 0 & 445 & 557 & 1002 \\
\hline 13 & $\begin{array}{c}\text { Kompong } \\
\text { Speu }\end{array}$ & 106 & 180 & 171 & 118 & 146 & 246 & 95 & 72 & 32 & 13 & 0 & 0 & 22 & 13 & 655 & 636 & 0 & 0 & 1227 & 1278 & 2505 \\
\hline 14 & Svay Rieng & 57 & 42 & 38 & 24 & 78 & 42 & 15 & 13 & 5 & 5 & 0 & 0 & 3 & 0 & 112 & 30 & 0 & 0 & 308 & 156 & 464 \\
\hline 15 & Prey Veng & 238 & 144 & 124 & 81 & 102 & 234 & 83 & 60 & 26 & 19 & 0 & 0 & 23 & 16 & 368 & 324 & 0 & 0 & 964 & 878 & 1842 \\
\hline 16 & $\begin{array}{c}\text { Kompong } \\
\text { Cham }\end{array}$ & 139 & 138 & 87 & 100 & 78 & 258 & 55 & 45 & 24 & 15 & 0 & 0 & 11 & 10 & 451 & 390 & 0 & 0 & 845 & 956 & 1801 \\
\hline 17 & kratie & 79 & 66 & 87 & 64 & 58 & 216 & 89 & 70 & 15 & 9 & 0 & 0 & 4 & 4 & 550 & 618 & 0 & 0 & 882 & 1047 & 1929 \\
\hline 18 & $\begin{array}{l}\text { Kompong } \\
\text { Thom }\end{array}$ & 147 & 90 & 85 & 50 & 111 & 108 & 78 & 46 & 11 & 8 & 0 & 0 & 4 & 11 & 316 & 246 & 0 & 0 & 752 & 559 & 1311 \\
\hline 19 & Siem Reap & 580 & 420 & 361 & 248 & 242 & 438 & 138 & 104 & 46 & 45 & 0 & 0 & 51 & 38 & 1679 & 1818 & 0 & 0 & 3097 & 3111 & 6208 \\
\hline 20 & $\begin{array}{c}\text { Oddar } \\
\text { Meanchey }\end{array}$ & 59 & 96 & 72 & 70 & 61 & 84 & 11 & 14 & 12 & 10 & 0 & 0 & 5 & 5 & 197 & 222 & 0 & 0 & 417 & 501 & 918 \\
\hline 21 & Preah Vihear & 47 & 66 & 65 & 52 & 5 & 150 & 31 & 15 & 14 & 11 & 0 & 0 & 6 & 7 & 107 & 204 & 0 & 0 & 275 & 505 & 780 \\
\hline 22 & Stung Treng & 13 & 54 & 48 & 14 & 50 & 78 & 6 & 9 & 6 & 1 & 0 & 0 & 0 & 1 & 57 & 102 & 0 & 0 & 180 & 259 & 439 \\
\hline 23 & Ratanakiri & 66 & 78 & 91 & 56 & 294 & 336 & 56 & 48 & 9 & 9 & 0 & 0 & 13 & 4 & 12 & 204 & 0 & 0 & 541 & 735 & 1276 \\
\hline 24 & Mondulkiri & 31 & 30 & 27 & 29 & 29 & 60 & 12 & 9 & 2 & 1 & 0 & 0 & 0 & 1 & 94 & 60 & 0 & 0 & 195 & 190 & 385 \\
\hline 25 & $\begin{array}{l}\text { Tboung } \\
\text { Khmum }\end{array}$ & 181 & 108 & 88 & 72 & 57 & 198 & 76 & 53 & 10 & 9 & 0 & 0 & 5 & 2 & 304 & 384 & 0 & 0 & 721 & 826 & 1547 \\
\hline & Total & 4145 & 2904 & 2797 & 1984 & 2334 & 4680 & 1463 & 976 & 554 & 375 & 0 & 0 & 304 & 219 & 12178 & 9846 & 0 & 0 & 23,775 & 20,984 & 44,759 \\
\hline
\end{tabular}


Table 2. Number of children by disability at each secondary school in Cambodia.

\section{Secondary School}

Visual Hearing Speech Movement Behavioral Learning Intellectual Emotional impairmentimpairmentimpediment disorder disorder disability disability disturbance

Others Total

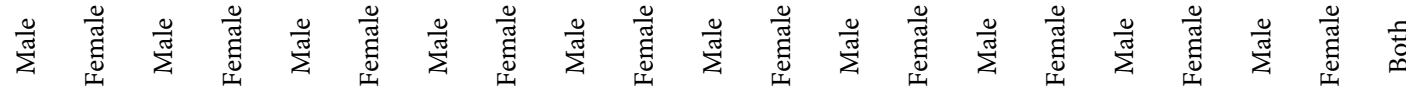

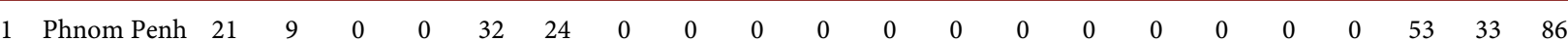

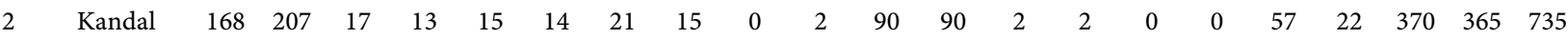

$\begin{array}{lllllllllllllllllllllll}3 & \text { Takeo } & 31 & 39 & 0 & 0 & 13 & 9 & 0 & 0 & 0 & 0 & 0 & 0 & 0 & 0 & 0 & 0 & 22 & 15 & 66 & 63 & 129\end{array}$

$\begin{array}{lllllllllllllllllllllll}4 & \text { Kampot } & 37 & 25 & 0 & 0 & 4 & 4 & 0 & 0 & 0 & 0 & 0 & 0 & 0 & 0 & 0 & 0 & 41 & 24 & 82 & 53 & 135\end{array}$

$\begin{array}{lllllllllllllllllllllll}5 & \text { Kep } & 9 & 9 & 4 & 1 & 1 & 2 & 3 & 0 & 0 & 0 & 15 & 11 & 0 & 0 & 0 & 0 & 1 & 0 & 33 & 23 & 56\end{array}$

$\begin{array}{llllllllllllllllllllllllll}\text { Preash } & 9 & 10 & 8 & 3 & 3 & 2 & 1 & 2 & 0 & 1 & 1 & 3 & 0 & 1 & 0 & 0 & 0 & 0 & 22 & 22 & 44\end{array}$

Sihanouk

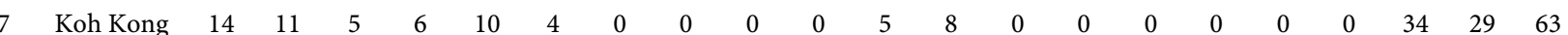

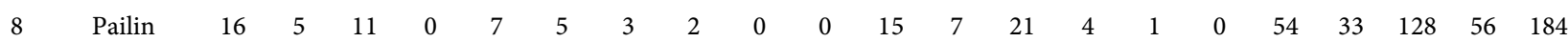

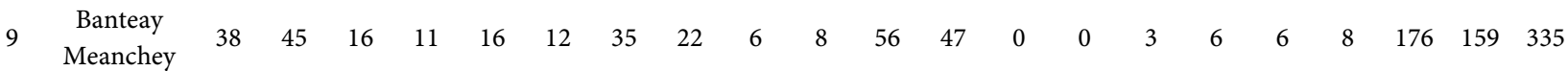

10 Battambang $94 \begin{array}{llllllllllllllllllll}104 & 23 & 20 & 25 & 11 & 21 & 14 & 0 & 0 & 64 & 43 & 0 & 0 & 10 & 12 & 60 & 65 & 297 & 269 & 566\end{array}$

$\begin{array}{lllllllllllllllllllllll}11 & \text { Pursat } & 71 & 92 & 27 & 35 & 19 & 14 & 9 & 12 & 0 & 0 & 87 & 74 & 0 & 0 & 5 & 4 & 66 & 62 & 284 & 293 & 577\end{array}$

$\begin{array}{llllllllllllllllllllll}\text { Kompong } & \\ \text { Chhnang } & 59 & 50 & 22 & 22 & 24 & 16 & 6 & 8 & 0 & 0 & 76 & 53 & 0 & 0 & 4 & 5 & 98 & 80 & 289 & 234 & 523\end{array}$

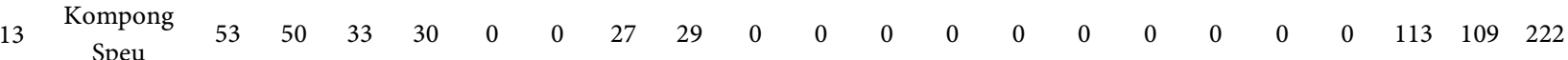

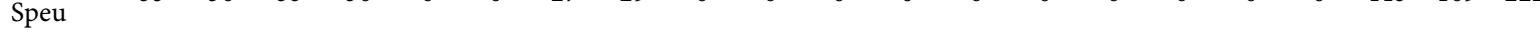

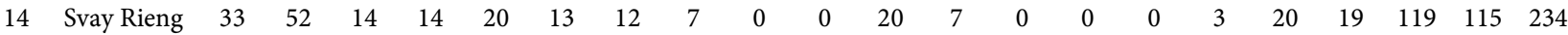

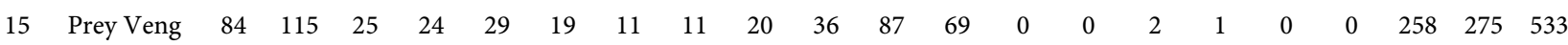

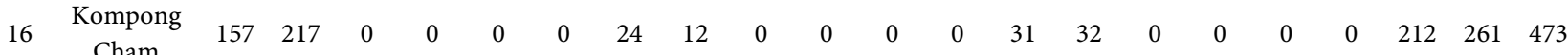

$\begin{array}{lllllllllllllllllllllll}17 & \text { kratie } & 64 & 77 & 17 & 20 & 17 & 12 & 3 & 2 & 0 & 0 & 81 & 89 & 0 & 0 & 1 & 4 & 90 & 80 & 273 & 284 & 557\end{array}$

$18 \begin{gathered}\begin{array}{c}\text { Kompong } \\ \text { Thom }\end{array} \\ 15\end{gathered}$

19 Siem Reap $17 \begin{array}{lllllllllllllllllllll} & 15 & 6 & 3 & 0 & 0 & 13 & 24 & 0 & 0 & 0 & 0 & 0 & 0 & 0 & 0 & 0 & 0 & 36 & 42 & 78\end{array}$

$\begin{array}{lllllllllllllllllllllll}\text { Oddar } & 3 & 2 & 0 & 0 & 0 & 0 & 8 & 4 & 0 & 0 & 0 & 0 & 0 & 0 & 0 & 0 & 0 & 0 & 11 & 6 & 17\end{array}$

Meanchey

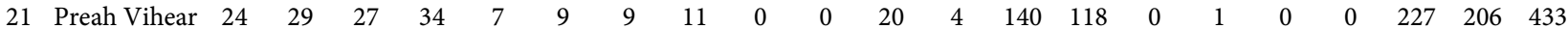

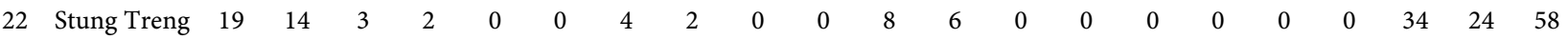

23 Ratanakiri $64 \begin{array}{lllllllllllllllllllll} & 64 & 25 & 9 & 4 & 0 & 5 & 2 & 8 & 2 & 40 & 36 & 15 & 14 & 1 & 0 & 0 & 0 & 162 & 111 & 273\end{array}$

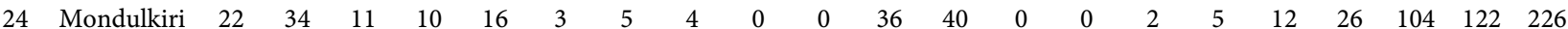

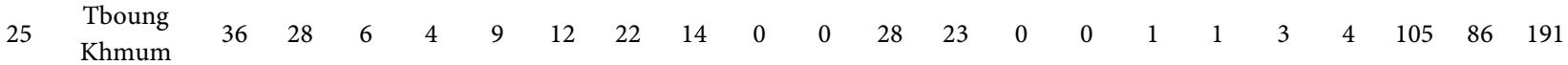

$\begin{array}{llllllllllllllllllllll}\text { Total } & 1158 & 1301 & 304 & 262 & 271 & 185 & 255 & 207 & 34 & 49 & 730 & 610 & 209 & 171 & 31 & 42 & 530 & 438 & 3522 & 3265 & 6787\end{array}$ 
Table 3. Number of students in special schools for the visual impaired.

\begin{tabular}{ccccc}
\hline & Number of classes & Male & Female & Total students \\
\hline Phnom Penh & 41 & 66 & 19 & 85 \\
Kampong Cham & 12 & 67 & 28 & 95 \\
Battambang & 13 & 28 & 6 & 34 \\
Siem Reap & 12 & 21 & 8 & 29 \\
Total & 78 & 182 & 61 & 243 \\
\hline
\end{tabular}

Table 4. Number of students in special schools for the hearing impaired.

\begin{tabular}{ccccc}
\hline & Number of classes & Male & Female & Total students \\
\hline Phnom Penh & 12 & 90 & 37 & 127 \\
Kampong Cham & 12 & 89 & 31 & 120 \\
Battambang & 13 & 66 & 30 & 96 \\
Siem Reap & 13 & 100 & 40 & 140 \\
Total & 50 & 345 & 138 & 483 \\
\hline
\end{tabular}

Training for junior high school teachers and early childhood education teachers is underway. After completing training certification is provided, however there is no associated increase in salary or stipend.

Another NGO operating educational programs for children with disabilities is Rabbit-School, founded in Phnom Penh in 1997. Its mission is to educate children with intellectual disabilities. Rabbit-School is located in the building of the National Borey for Infants and Children and coordinates with the government, although it does not receive public financial support. The number of students accepted was not documented by the government. However, according to the report of Mamada in 2013 (Muroda, 2013), there were 26 students in the special class, 25 students in the readiness class for children aged 4-to-6 years, 18 students in classes for children with cerebral palsy, and 46 students in the integrated class. Five teachers and ten assistants worked there.

The third NGO is the Komar Pilar Foundation. This NGO was founded in 2001 and has one center and two schools, one in Phnom Penh and the other in Kanpot. However, these schools do not coordinate with the government and are not officially regarded as schools. In the health sector, an NGO named Center for Child and Adolescent Mental Health carried out inspections and support for children with intellectual disability.

\section{Discussion}

This paper is the first report showing the number of children with disabilities in each Cambodian province. Although there are limitations, such as the small number of children with disabilities identified compared to the overall population and the potential form is identifying some disabilities, it is notable that 
these statistics have been gathered nationwide. Training for general education teachers is required so that disability checklists are more accurately used at school sites. Currently, there are only four special schools in the whole country for students with visual or hearing impairments. For children with intellectual disabilities, there is only one school in Phnom Penh.

The total number of students with all disabilities was 44,759 in primary schools and 6787 in secondary schools. The most common disability was emotional disturbance in primary schools and visual impairment in secondary schools. The data show that the number of "invisible disabilities" such as behavioral disorders, learning disability, intellectual disability, and emotional disturbance varied considerably across provinces. The misidentification of disabilities can be considered a cause for this variation. The number of students served is also very small, and many children with disabilities are left behind in general schools or alienated from education under the guise of inclusive education. In Cambodia, the quality of regular education in the public school system is not always adequately maintained, and training teachers on the special needs of children with disabilities may be premature. In the meantime, more special schools, staffed with adequately trained professionals, are needed to establish a firm foundation for serving the educational needs of children with disabilities in Cambodia. To adequately develop the requisite human resources, cooperation with universities in the international community is expected.

\section{Conclusion}

This paper is the first report showing the number of children with disabilities in each Cambodian province. The total number of students with all disabilities was 44,759 in primary schools and 6787 in secondary schools. The most common disability was emotional disturbance in primary schools and visual impairment in secondary schools. The data show that the number of "invisible disabilities" such as behavioral disorders, learning disability, intellectual disability, and emotional disturbance varied considerably across provinces. The misidentification of disabilities can be considered a cause for this variation.

\section{Conflicts of Interest}

The author declares no conflicts of interest regarding the publication of this paper.

\section{References}

(1989). Convention on the Rights of Children. https://www.ohchr.org/en/professionalinterest/pages/crc.aspx

(2006). Convention on the Rights of Persons with Disabilities and Optional Protocol. http://www.un.org/disabilities/documents/convention/convoptprot-e.pdf

(2007). Education Law, Kingdom of Cambodia. http://www.moeys.gov.kh/images/moeys/laws-and-regulations/48/EducationLaw-EN.p df 
(2008). Education Policy for Children with Disabilities in Cambodia.

http://www.moeys.gov.kh/en/press-releases/policy-on-education-for-children-with-dis abilities.html\#.WnBmH65l_cs

(2009). Cambodian Law on the Protection and the Promotion of the Rights of Persons with Disabilities.

http://www.ilo.org/dyn/natlex/docs/ELECTRONIC/86089/96925/F217191771/KHM86 089\%20English.pdf

(2010). The Constitution of the Kingdom of Cambodia. http://www.wipo.int/edocs/lexdocs/laws/en/kh/kh009en.pdf

ADB Economics Working Paper Series (2011). Poverty in Asia and the Pacific: An Up date. https://www.adb.org/sites/default/files/publication/29051/economics-wp267.pdf

Ayres, D. M. (2000). Anatomy of a Crisis: Education, Development, and the State in Cambodia, 1953-1998. Honolulu, HI: University of Hawaii Press.

Bilodeau, C., Pathammavong, S., \& Hông, L. Q. (1955). Compulsory Education in Cambodia, Laos and Viet-Nam. Switzerland: UNESCO.

Cambodia GDP (2019). Gross Domestic Product. https://countryeconomy.com/gdp/cambodia?year=2014

Chankea, P. (2013). A Historical Transition of the Educational System in Cambodia: Social Characteristics in the Education System before the Paris Peace Agreement. Papers of Pedagogy, 9, 177-197.

David, M. (2000). Ayres: Anatomy of a Crisis: Education, Development, and the State in Cambodia, 1953-1998. Honolulu: University of Hawaii Press.

Hatani, S. (2011). Educational Reform in Cambodia under the Hen-Samrin Administration and the National Statue in the Textbook. Ritsumeikan International Studies, 23, 559-580. (In Japanese)

Masson, G. L., \& Fergusson, L. C. (1997). A Culture under Siege: Post-Colonial Higher Education and Teacher Education in Cambodia from 1953 to 1979. History of Education, 26, 91-112. https://doi.org/10.1080/0046760970260106

Muroda, K. (2013). Report on Special Education in Cambodia (2) Integrated Education Pilot School, Local Blind and Dormitory School, Intellectual Disabled Facility/Phone Impaired Facility. Tsukuba University Special Support Education Research, 7, 70-76. (In Japanese)

UNICEF East Asia \& Pacific Regional Office (2003). Inclusive Education Initiatives for Children with Disabilities: Lessons from East Asia and Pacific Region. http://docplayer.net/11021897-Unicef-unicef-inclusive-education-initiatives-for-childr en-with-disabilities-lessons-from-the-east-asia-and-pacific-region-unicef.html 